\title{
Factors of Job Satisfaction in The Czech Republic
}

Dr.Vaclav Stritesky

Department of marketing, Faculty of Business Administration | Prague University of Economics and

Business

\begin{abstract}
:
Purpose: The paper aims to identify overall job satisfaction in the Czech Republic and explore its differences between the various economic sectors. It also provides a comprehensive view of potential influence factors on job satisfaction with the emphasis on sociodemographic variables and job characteristics. This study aims to offer a different perspective on the issue of job satisfaction, which is often analysed in conditions of one specific organization. In the Czech Republic, a study analysing the global situation of job satisfaction in terms of sociodemographic variables have not been published yet.
\end{abstract}

Design/methodology/approach: The study is based on the quantitative research using personal interviews. Data was collected in cooperation with the research agency Median, s.r.o. within its research project Market \& Media \& Lifestyle. The size of the sample is over 15,000 respondents. Tests for the homogeneity of binomial proportions and logistic regression are used.

Findings: The paper provides a comprehensive view of job satisfaction on the Czech market. The influencing factors of job satisfaction are discussed. These results can be used when assessing the level of job satisfaction of various groups of Czech employees in terms of specific companies.

Research/practical implications: The paper includes implications for assessing the effectiveness of various HR policies on job satisfaction of various groups of employees in the Czech Republic. This comprehensive macro perspective on the issue of job satisfaction may lead to the conclusion that some socio-demographic groups of employees may generally exhibit lower level of job satisfaction regardless of the specific conditions of the company.

Originality/value: This paper provides a different perspective on the issue often examined in the conditions of Czech Republic, which is still missing and is frequently published in other countries.

Keywords: job, job satisfaction, HR policy, labour market, motivation

JEL Codes: M00, M12, M52.

\section{Introduction}

Employee satisfaction is a crucial issue in the current business environment. The new situation on the labour market caused by the current phase of the economic cycle is the main concern of enterprises in Central Europe. Long-term challenge is the changing content of jobs, ranging from routine activities towards heuristic tasks. This fact significantly affects the value of human resources in business. Some researchers present the risk of a lack of specific qualifications in the labour market, which poses a challenge for businesses to reduce employee fluctuation and stabilize good staff (Bosworth, Jones, and Wilson, 2008).Other risks in this area stem from the overqualified workforce (Croce and Ghignoni, 2012).Both cases are also a reason to solve the problem of employee satisfaction.

Nowadays, many papers and studies dealwith employee satisfaction and its factors. Some of the employee satisfaction factors are examined in the chosen sectors, such as banking industry, IT, public services etc. (Shan, Yao, Shi and Ren, 2014; Tso, Fai and Li, 2015). Other studies are designed in broader dimensions. They examine the impact of socio- 
demographic factors on the level of employee satisfaction in specific areas of working life (Urosevic and Milijic, 2012; Tomazevic, Seljak and Aristovnik, 2014).

In conditions of the Czech labour market only studies focusing on specific sectors or specific factors were published (Němečková, 2012; Sokolová, Mohelská and Zubr, 2016). Research on complex factors of employee satisfaction on the Czech labour market has not been publishedyet. The paper aims to identify overall job satisfaction in the Czech Republic and explore its differences between the various economic sectors. It also provides a comprehensive view of potential influence factors on job satisfaction with the emphasis on sociodemographic variables and job characteristics.

\section{Data and Methods}

Data for this analysis were collected in cooperation with research agency Median within the research project Market \& Media \& Lifestyle. Sample size is over 15000 respondents. Data collection was based on personal interviews; random sampling was used. The sample is representative to the Czech population aged $12-79$. Analysis for this study was focused on labour force. Some segments such as retired people, students, children, the unemployed were filtered out. Final sample size was 9004 respondents. Data were collected during 4 periods in 2014.

Main part of the study aims to evaluate influence of sociodemographic characteristics and job characteristics on job satisfaction. Investigated variables are gender, age, education and net income as sociodemographic ones. As for job characteristics, economic sector in which the respondent works or does business, size of the company, status in employment,financial decision-making power and the type of employment (employee, entrepreneur) are investigated.

Significance of identified difference are evaluated through the testsfor equality of means. Tests for the homogeneity of binomial proportions were used. Logistic regression is an additional method for assessing the significance of variables and their ability to predict job satisfaction.

\section{Results}

\subsection{Overall job satisfaction}

The research explored overall job satisfaction in the Czech Republic. Almost $60 \%$ of Czech workers are satisfied with their job (see Fig. 1). It is relatively high rate of job satisfaction as only $4 \%$ of Czech labour force are definitely unsatisfied.

Figure 1: Overall job satisfaction in the Czech Republic

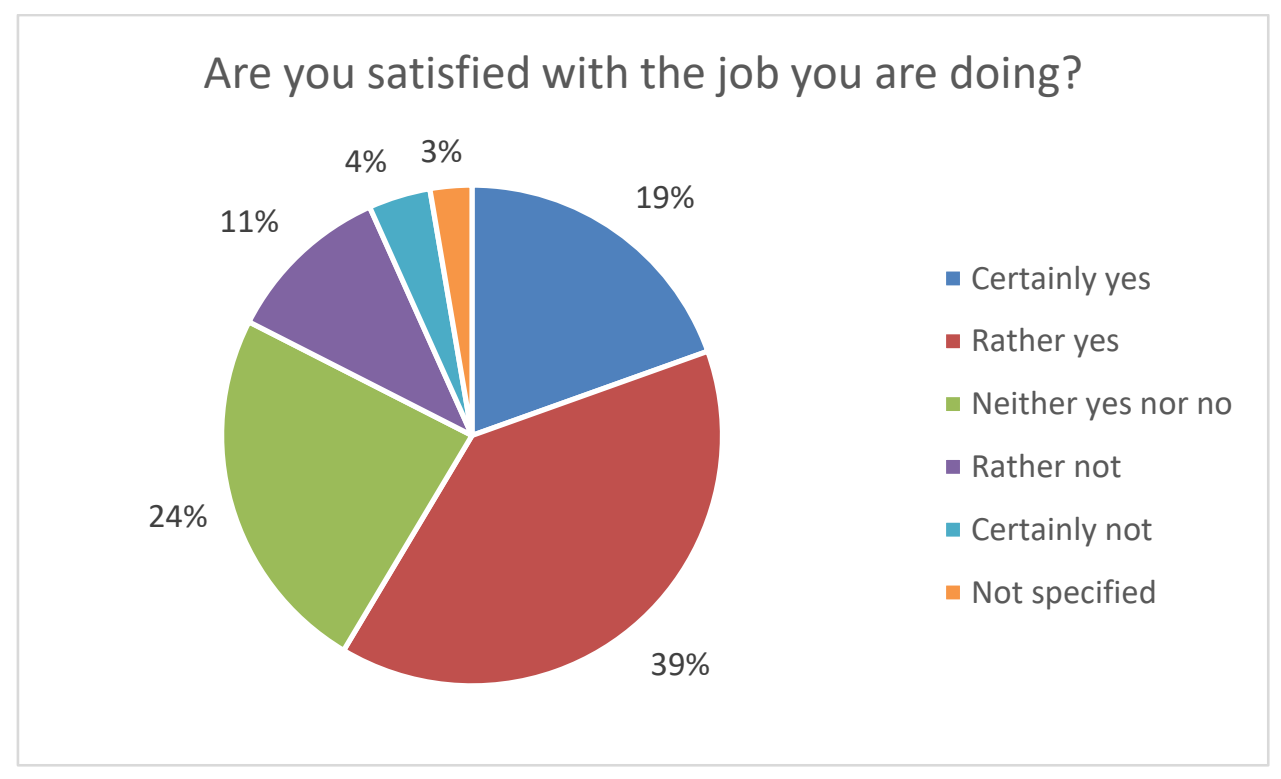

Source: authors, MML-TGI, Median 2014, N = 9004

\subsection{Analysis of sociodemographic variables}


Differences between men and women are not statistically significant (p-value $=0,89$ ). $58.6 \%$ of male labour force and $58.5 \%$ of female labour force are satisfied with their job. See Tab. 1.

Table 1: Sociodemographic variables and their significance

\begin{tabular}{|r|c|c|}
\hline \multicolumn{1}{|c|}{ Variable } & p-value & Significance \\
\hline Gender & 0.89 & no \\
\hline Age & 0,00 & yes \\
\hline Age 16-24 vs. others & 0.00 & yes \\
\hline Age 16-54 vs. others & 0.00 & yes \\
\hline Age 25-54 vs. others & 0.29 & no \\
\hline Education & 0,00 & yes \\
\hline Net income & 0,00 & yes \\
\hline
\end{tabular}

Source: authors, MML-TGI, Median 2014, N = 9004

Depending on age intervals definition the analysis confirmed age as a significant variable influencing job satisfaction. We can say that younger people are less satisfied with their job, namely people in the age of $16-24$ (only $50.8 \%$ are satisfied with their job compared to $61.7 \%$ of 55+). On the other hand, middle aged people do not differ significantly in job satisfaction compared to other age groups ( $58.3 \%$ of people aged $25-54$ compared to $59.6 \%$ of other people). Education was identified as a significant variable. The higher education the higher rate of job satisfaction. Labour force with primary education has the lowest rate of job satisfaction (47.7\%). On the contrary, people with higher education have the highest rate of job satisfaction $(69.1 \%)$. Secondary education without graduation and secondary education with graduation were joined together as these two groups were characterised with similar rate of job satisfaction. In average, $57.5 \%$ of labour force with secondary education are satisfied with the job.

Net income is a significant variable but the relation between job satisfaction and the size of net income is not linear as people with salary above CZK 100000 are much less satisfied (61,4\%) compared to people with salary CZK 75001 $100000(96.8 \%)$ or even CZK 50001 - 75000 (96.7\%). Despite this fact, the analysis confirmed that job satisfaction grows with higher income. Rates of job satisfaction for broadly defined intervals of net income are as follows:

- $\quad$ Up to CZK 10 000: $43.6 \%$;

- $\quad$ CZK $10001-20$ 000: $55.8 \%$;

- $\quad$ CZK 20001 - 50 000: $66.5 \%$;

- $\quad$ CZK 50001 and more: $86.2 \%$

The research identified net income CZK 50000 as a breaking point of substantial growth of job satisfaction. $62.1 \%$ of labour force with income CZK 40001 - 50000 are satisfied with their jobs compared to $96.7 \%$ of labour force with net income CZK 50000 - 75 000. These findings were important for defining the income intervals above. Dividing middle interval CZK 20001 - 50000 into smaller ones did not result in significant differences between them. Similarly, net income interval CZK 50001 - 75000 and CZK 75000 and more.

\subsection{Job characteristics}

Next part of the analysis explored selected job characteristics and their relation to job satisfaction. Statistical significance of identified differences was tested by the test for equality of means. Analysed variables were as follows:

- $\quad$ economic sector in which the respondent works or does business,

- number of employees in the company where the respondent works, 
- $\quad$ status in employment,

- $\quad$ financial decision-making power in the respondent's employment,

- $\quad$ type of employment (employee, entrepreneur).

One of the analysed characteristics was the economic sector in which the respondent works or does business. Tab. 2 presents the ranking of sectors per job satisfaction.

Table 2: Ranking of selected economic sectors according to the job satisfaction

\begin{tabular}{|l|l|l|l|l|c|}
\hline 1. & Education/Science & $72.1 \%$ & 8. & $\begin{array}{l}\text { Public administration } \\
\text { judicial/military / police }\end{array}$ & $58.2 \%$ \\
\hline 2. & IT & $70.9 \%$ & 9. & Construction/Real Estate & $56.9 \%$ \\
\hline $3 .-4$. & Other technical fields & $68.3 \%$ & $10 .-11$. & Banking/ finance & $56.8 \%$ \\
\hline $3 .-4$. & $\begin{array}{l}\text { Marketing/Management/ } \\
\text { Advertising/Media }\end{array}$ & $68.3 \%$ & $10 .-11$. & Services / Tourism & $56.8 \%$ \\
\hline 5. & Health/Social Care & $64.8 \%$ & $12 .-13$. & Transport/Logistics & $56.4 \%$ \\
\hline 6. & $\begin{array}{l}\text { Agriculture / Environment/ } \\
\text { Ecology }\end{array}$ & $60.6 \%$ & $12 .-13$. & Manual work & $56.4 \%$ \\
\hline 7. & $\begin{array}{l}\text { Industry/production/ extraction } \\
\text { of raw materials/metallurgy }\end{array}$ & $59.5 \%$ & 14. & $\begin{array}{l}\text { Trade - buying and selling } \\
\text { of goods }\end{array}$ & $50.6 \%$ \\
\hline
\end{tabular}

Source: authors, MML-TGI, Median 2014, N = 9004

This variable is significant ( $\mathrm{p}$-value $<0,05$ ), differences in job satisfaction between particular economic sectors exist. Closer analysis did not prove significant difference among all the sectors. Some of them are similar to others.

Economic sectors with significant difference in job satisfaction compared to other sectors are as follows:

- Health / Social Care;

- IT;

- Other technical fields;

- $\quad$ Education / Science;

- $\quad$ Trade - buying and selling of goods.

Next tested variable was the number of employees in the company which correspond to the company size.Overall, testfor the homogeneity of binomial proportions showed a statistically significant difference ( $\mathrm{p}$-value $<0.05)$. Biggest difference in job satisfaction was founded out between companies with 1 employee (generally independent entrepreneurs) and companies above 100 employees. $64.1 \%$ of independent entrepreneurs are satisfied compared to $55.6 \%$ in larger companies above 100 employees. Larger companies have similar rate of job satisfaction to companies of $6-25$ employees (56.9\%). On the other hand, relatively high satisfaction was proven in companies of $26-100$ employees $(62.4 \%)$. Relation between the company size and job satisfaction is not linear.

Status in employment is next significant variable which influences job satisfaction. Differences were statistically significant both at the 0.05 and 0.01 level. Analysis confirmed that job satisfaction is increasing with higher status in employment. Highest rate of job satisfaction was founded out among directors of the companies (94.6\%). On the contrary, lowest level of satisfaction stated ordinary (frontline) employees (56.5\%). Equal mean of job satisfaction (i.e., not significant difference of job satisfaction compared to other samples) was identified among managers with subordinate units $(66.8 \%)$. This status in employment does not imply statistically different job satisfaction ( $\mathrm{p}$-value = $0,08)$. 
Financial decision-making power showed as a significant factor, too. Generally, people with greater decision-making power in finance are more likely to be satisfied with their job. An interesting exception are people with the responsibility for highest budgets above CZK 5 mil. Their level of satisfaction is much lower and is not significantly different from other people (see Tab 3.).

Table 3: Job satisfaction related to financial decision-making power

\begin{tabular}{|l|c|c|}
\hline \multicolumn{1}{|c|}{ Financial decision-making power } & Satisfied with the job & p-value (binomial test) \\
\hline Do not decide on financial flows & $57.7 \%$ & 0,00 \\
\hline CZK 50 - 250 thousand & $65.2 \%$ & 0,00 \\
\hline CZK 250 thousand-1 million & $68.9 \%$ & 0,00 \\
\hline CZK 1 million - 5 million & $77.0 \%$ & 0,00 \\
\hline Above CZK 5 million & $56.7 \%$ & 0,61 \\
\hline
\end{tabular}

Source: authors, MML-TGI, Median 2014, N = 9004

Last variable included in the analysis was the type of employment. Main aim was to identify difference in job satisfaction between employers and entrepreneurs. Aggregated data shows that private entrepreneurs are more satisfied with their job compared to employed people:

- $\quad$ Private entrepreneurs: $66.0 \%$.

- $\quad$ Employed people: $57.9 \%$.

The difference is significant at the 0.01 level.

Interesting findings offered an analysis of this variable in more detail (see Tab. 4). The highest rate of job satisfaction was identified among entrepreneurs without employees (i.e., independent entrepreneurs). On the contrary, least satisfied are part-time employees. Binomial test compared values of job satisfaction rate between selected category and the rest of respondents. As p-values in Tab. 4 show, only private entrepreneurs without employees and part-time employees differ significantly from the average satisfaction of other types of employment (at the level of significance $0.05)$.

Table 4: Job satisfaction related the type of employment

\begin{tabular}{|l|c|c|}
\hline \multicolumn{1}{|c|}{ Type of employment } & Satisfied with the job & p-value (binomial test) \\
\hline employed/ sole job/ full time & $58.5 \%$ & 0,77 \\
\hline $\begin{array}{l}\text { employed / two or more jobs or employed and self- } \\
\text { employed }\end{array}$ & $54.5 \%$ & 0,13 \\
\hline employed/part-time or part-time & $50.7 \%$ & 0,00 \\
\hline $\begin{array}{l}\text { private entrepreneur (owner / co-owner of the company) } \\
\text { without employees }\end{array}$ & $67.4 \%$ & 0,00 \\
\hline $\begin{array}{l}\text { private entrepreneur (owner / co-owner of the company) } \\
\text { with employees }\end{array}$ & $61.8 \%$ & 0,33 \\
\hline other & $52.8 \%$ & 0,14 \\
\hline
\end{tabular}

Source: authors, MML-TGI, Median 2014, N = 9004

\subsection{Modelling of job satisfaction through logistic regression}

Significance of variables described above was evaluated also through logistic regression. Main aim of this part of the analysis is to answer the question if sociodemographic characteristics and characteristics of the job itself can be used for modelling job satisfaction. 
Dependent variable is an agreement with the statement that the respondent is satisfied at work. Independent variables are sociodemographic characteristics and characteristics of the job. They are as follows:

- age,

- education,

- net income,

- $\quad$ economic sector - education / science,

- $\quad$ economic sector - IT,

- $\quad$ economic sector - other technical fields,

- $\quad$ economic sector - marketing / management / advertising / media,

- $\quad$ size of the company,

- $\quad$ status in employment,

- financial decision-making power.

Table 5: Outputs of logistic regression

\begin{tabular}{|l|c|c|c|c|}
\hline & Parameter est. & Std. error & Test statistics & p-value \\
\hline Intercept & $-1,15$ & 0,17 & 44,7 & 0,00 \\
\hline Independent variables & & & & \\
\hline Age & 0,10 & 0,02 & 16,5 & 0,00 \\
\hline Education & 0,09 & 0,04 & 5,78 & 0,02 \\
\hline Net income & 0,11 & 0,01 & 54,54 & 0 \\
\hline Sector- education/ science & 0,48 & 0,12 & 15,72 & 0 \\
\hline Sector -IT & 0,42 & 0,18 & 5,36 & 0,02 \\
\hline Sector- other technical fields & 0,42 & 0,16 & 7,39 & 0,01 \\
\hline Sector-marketing/ . & 0,81 & 0,31 & 7,03 & 0,01 \\
\hline Size of the company & $-0,05$ & 0,03 & 4,34 & 0,04 \\
\hline Status in employment & 0,19 & 0,05 & 14,19 & 0 \\
\hline Fin. decision-making power & $-0,07$ & 0,02 & 10,53 & 0 \\
\hline
\end{tabular}

Source: authors, MML-TGI, Median 2014, N = 9004

Counted levels of significance for each variable confirm the relevance of analysed factors influencing job satisfaction. Most of the factors are significant at the 0,01 level, education and size of the company at the 0,05 level.

Significance level for the model is 0,00 . On the other hand, coefficient of determination is very low $(0,02)$. It means that this model is probably not suitable for explanation and prediction of job satisfaction. Hard variables such as sociodemographic characteristics and characteristics of the job are not sufficient. Preliminary analysis of other models based also on lifestyle variables showed that this type of independent variables has much better potential to predict job satisfaction. Coefficient of determination was between $0,2-0,3$. This could be a basis for further research in this field. Job satisfaction is probably determined by a complex system of variables and will be generally difficult to predict.

\section{Conclusion}

The findings of this research can be used in designing incentive programs of businesses in the Czech Republic. Expected impact of individual actions and tools can be corrected just in the context of moderating factors of employee satisfaction.

Findings of this study confirm that Czech labour force is characterised by a relatively high rate of job satisfaction. Most of sociodemographic characteristics except of gender have significant influence on job satisfaction. Young people are more likely to be less satisfied compared senior people. Higher job satisfaction was also proved among labour force with higher education and higher net income. Net income of CZK 50 thousand was identified as a breaking point in job satisfaction.

As for job characteristics this study has brought interesting findings. Economic sectors with the highest level of job satisfaction are education / science and IT. People working in big-size companies above 100 employees feel much less satisfied with their job as independent entrepreneurs. Relatively high level of job satisfaction was identified among people working at companies with $26-100$ employees. The relationship between these variables is not linear. Status in employment was also identified as a significant variable. Especially, difference in job satisfaction between company 
directors and ordinary employees is of high range. People with greater decision-making power in finance are more likely to be satisfied with their jobexcept of people dealing with budgets above CZK 5 mil. This responsibility decreases job satisfaction again. Very interesting findings resulted from the analysis of the type of employment. Generally, private entrepreneurs are more satisfied with their job than employed people. Highest level of job satisfaction was identified among independent entrepreneurs without employees.

Logistic regression confirmed statistical significance for most of investigated variables. On the other hand, due to very low coefficient of determination, sociodemographic variables and variables describing various job characteristics are not sufficient for predicting job satisfaction. Based on preliminary analysis it was found out that variables regarding work lifestyle and values are much more better predictors than sociodemographic and job characteristics. Factors influencing job satisfaction are probably hidden behind psychological characteristics of people. This hypothesis will be investigated in next steps of this research.

\section{References}

- Bosworth, D., Jones, P., \& Wilson, R. (2008). The Transition to a Highly Qualified Workforce. Education Economics, 16(2), 127-147. Crossref

- Croce, G., \&Ghignoni, E. (2012). Demand and supply of skilled labour and overeducation in europe: A countrylevel analysis. Comparative Economic Studies, 54(2), 413-439. Crossref

- Němečková, I. (2012). Education as employee motivation and retention factor of the companies operating in the Czech Republic. Central European Business Review, 1(1), 33-37. Crossref

- Shan, S., Li, C., Yao, W., Shi, J., \& Ren, J. (2014). An Empirical Study on Critical Factors Affecting Employee Satisfaction. SystemsResearch \&Behavioral Science, 31(3), 447-460. Crossref

- Sokolová, M., Mohelská, H., \&Zubr, V. (2016). Pay and Offer of Benefits as Significant Determinants of Job Satisfaction - A Case Study in The Czech Republic. E+M Ekonomie a Management, 19(1), 108-120. Crossref

- Tso, G. K., Fai, Liu, F., \& Li, J. (2015). Identifying factors of employee satisfaction: A case study of chinese resource-based state-owned enterprises. Social Indicators Research, 123(2), 567-583. Crossref

- Tomazevic, N., Seljak, J., \&Aristovnik, A. (2014). Factors influencing employee satisfaction in the police service: The case of slovenia. Personnel Review, 43(2), 209-227. $\underline{\text { Crossref }}$

- Urosevic, S., \&Milijic, N. (2012). Influence of demographic factors on employee satisfaction and motivation. Organizacija, 45(4), 174. $\underline{\text { Crossref }}$

\section{Contact}

Marek Stř́iteský

University of Economics, Prague

Faculty of Business Administration, Department of Human Resource Management

W. Churchill Sq. 4

13067 Prague 3

The Czech Republic

Email: marek.stritesky@vse.cz

Václav Stříteský

University of Economics, Prague 
Faculty of Business Administration, Department of Marketing

W. Churchill Sq. 4

13067 Prague 3

The Czech Republic 